\title{
Allergy to hamster - 4 case reports
}

\author{
Christiane Hilger $^{1 *}$, P Ved Dubey ${ }^{2}$, Delphine Lentz ${ }^{1}$, Martine Morisset ${ }^{3}$, Christiane Lehners $^{3}, \mathrm{~K}$ De Prabir ${ }^{2}$, \\ François Hentges ${ }^{1}$
}

From 5th International Symposium on Molecular Allergology (ISMA 2013)

Vienna, Austria. 6-7 December 2013

\section{Background}

Hamsters are increasingly popular as domestic pets. Different species can be found in the domestic setting: the Syrian (golden) hamster (Mesocricetus auratus), the European hamster (Cricetus cricetus), the Siberian hamster (Phodopus sungorus) and the Rhoborovski hamster (Phodopus roborovskii). Several cases of asthma upon contact with hamsters and anaphylaxis following hamster bites have been described, but the allergen(s) responsible are either unidentified or poorly characterized. In the Syrian hamster, salivary lipocalins were found to be specifically expressed in male submandibular glands. MSP (male specific submandibular salivary gland protein) is detectable in saliva as two major forms of 20.5 and $24 \mathrm{kDa}$. The objectives of the present study were to determine if MSP is an allergen, to analyse IgE reactive proteins in different hamster fur extracts and to determine patient reactivity to different extracts.

\section{Methods}

Hamster protein hair extracts were prepared from four different hamster species. Hamster-allergic patients were selected based on their clinical history and a positive $\operatorname{IgE}$ test to hamster epithelium. IgE reactive proteins were analysed by immunoblot. Recombinant MSP was expressed in E. coli. Natural MSP was purified from Syrian hamster and MSP anti-serum was raised in rabbits.

\section{Results}

Three of the patient sera (P2, P3, P4) had IgE antibodies against proteins of 20.5 and $24 \mathrm{kDa}$ of Syrian hamster fur extract. These proteins could be identified as MSP. Similar bands were visible in the extract of the European hamster. Two patients $(\mathrm{P} 1, \mathrm{P} 2)$ showed IgE reactive bands at 17-21.5 kDa in Siberian and Rhoborovski hamster extract. P1 and P2 were further characterized by basophil release assay. They reacted positively with both

${ }^{1}$ CRP-Santé, Infection \& Immunity, Luxembourg, Luxembourg

Full list of author information is available at the end of the article
Phodopus species, but negative with Syrian and European hamster. Both patients however reacted with fur extract of all 4 species in skin prick test.

\section{Conclusion}

The salivary lipocalin MSP was identified as allergen of the Syrian hamster. Cross-reactive proteins were detected in the European hamster. Major allergens of Siberian and Roborovski hamster seem to be different from those identified in the Syrian hamster.

\section{Authors' details}

${ }^{1}$ CRP-Santé, Infection \& Immunity, Luxembourg, Luxembourg. ${ }^{2}$ Centre for Cellular \& Molecular Biology, Mol Endocrinology, Biochemistry \& Mol Biology, Hyderabad, India. ${ }^{3}$ Centre Hospitalier de Luxembourg, National Unit of Allergology, Luxembourg, Luxembourg.

Published: 17 March 2014

doi:10.1186/2045-7022-4-S2-P40

Cite this article as: Hilger et al:: Allergy to hamster - 4 case reports. Clinical and Translational Allergy 2014 4(Suppl 2):P40.

Submit your next manuscript to BioMed Central and take full advantage of:

- Convenient online submission

- Thorough peer review

- No space constraints or color figure charges

- Immediate publication on acceptance

- Inclusion in PubMed, CAS, Scopus and Google Scholar

- Research which is freely available for redistribution
C Biomed Central

C 2014 Hilger et al; licensee BioMed Central Ltd. This is an Open Access article distributed under the terms of the Creative Commons Attribution License (http://creativecommons.org/licenses/by/2.0), which permits unrestricted use, distribution, and reproduction in any medium, provided the original work is properly cited. The Creative Commons Public Domain Dedication waiver (http:// creativecommons.org/publicdomain/zero/1.0/) applies to the data made available in this article, unless otherwise stated. 